\title{
THE EFFECT OF THE ADMINISTRATION OF SODIUM BICARBONATE AND AMMONIUM CHLORIDE ON THE EXCRETION AND PRODUCTION OF AMMONIA. THE ABSENCE OF ALTERATIONS IN THE ACTIVITY OF RENAL AMMONIA-PRODUCING EN- ZYMES IN THE DOG
}

\author{
By FLOYD C. RECTOR, JR. AND JACK ORLOFF WITH THE TECH NICAL ASSISTANCE OF \\ DORIS WOODS \\ (From the Laboratory of Kidney and Electrolyte Metabolism, National Heart Institute, \\ Bethesda, Md.)
}

(Submitted for publication August 20, 1958; accepted October 16, 1958)

The regulation of the excretion of ammonia by the kidney has been studied extensively. It is clear that urine $\mathrm{pH}$ is an important determinant of ammonia excretion, with greater amounts of ammonia diffusing into acid urines than into alkaline urines (1-8). However, it is also evident that the magnitude of the rise in ammonia excretion during the chronic administration of strong acids or acidifying salts cannot be accounted for solely on the basis of "trapping" of greater amounts of ammonia in increasingly acid urines. Thus Pitts (4) found that dogs given $\mathrm{NH}_{4} \mathrm{Cl}$ for two days excreted more ammonia at any given urine $\mathrm{pH}$ than did control animals, presumably due to increased production of ammonia by the renal tubule cells. Earlier, Van Slyke and co-workers (9) had found that the extraction of glutamine from renal arterial blood was greater in dogs receiving $\mathrm{NH}_{4} \mathrm{Cl}$ than in those receiving $\mathrm{NaHCO}_{3}$, and further that the extracted glutamine amide- $\mathrm{N}$ accounted for approximately 60 per cent of the ammonia produced by the kidney. Lotspeich and Pitts (10) postulated that the capacity of some renal mechanism, capable of extracting and hydrolyzing glutamine, increases during chronic metabolic acidosis to produce more ammonia. This was confirmed in rats when Davies and Yudkin (11) and others $(7,12)$ found that the administration of $\mathrm{HCl}$ increased and the administration of $\mathrm{NaHCO}_{3}$ decreased the activity of rat kidney glutaminase. The observation of similar changes in acidotic guinea pigs and rabbits (13) has suggested that ammonia excretion in all mammals, including man, is regulated in part by adaptive changes in the activity of renal glutaminase.

There is evidence, however, that the regulation of ammonia excretion differs in dogs and rats.
Orloff and Berliner (6) observed that the relationship between urine $\mathrm{pH}$ and ammonia excretion in dogs was reproducible following the infusion of sodium bicarbonate and independent of acute alterations in acid-base balance. This is in contrast to the findings of Leonard and Orloff (7) in the rat. In this species a correlation between ammonia excretion and urine $\mathrm{pH}$ was not observed under all circumstances. Alterations in ammonia excretion occurred independently of urine $\mathrm{pH}$ changes in some circumstances. The converse was also observed: changes in urine $\mathrm{pH}$ without associated changes in ammonia excretion. In the rat variations in ammonia excretion in acute studies are conditioned not only by urine $\mathrm{pH}$, the only determinant in the dog, but also by the state of acid-base balance. Dogs and rats also exhibit dissimilar urinary responses to the chronic inhibition of carbonic anhydrase. In rats treated chronically with acetazoleamide, ammonia excretion falls briefly, then rises to greater than normal levels. This elevated excretion of ammonia is associated with an increased activity of renal glutaminase $(7,14)$. In dogs, however, the chronic administration of acetazoleamide results in a persistent reduction in ammonia excretion, with a return towards normal values only as the urine becomes less alkaline (15). On the basis of the response of man (16) and dog (15) to acetazoleamide, it had been suggested (17) that an adaptive increase in the activity of renal glutaminase might not occur in these species.

The purpose of the present studies was to determine whether or not alterations in the activity of renal glutaminase participate in the regulation of ammonia excretion in dogs. The effects of $\mathrm{NH}_{4} \mathrm{Cl}$ and $\mathrm{NaHCO}_{3}$ on the relationship between 
ammonia excretion and the activities of the various renal enzymes involved in the conversion of glutamine to ammonia were examined in dogs and the results compared with those from essentially analogous studies in rats.

\section{PROCEDURES}

The relationship between ammonia excretion and urine $\mathrm{pH}$ in four trained female dogs was determined both after the administration of $8 \mathrm{Gm}$. of $\mathrm{NH}_{4} \mathrm{Cl}$ daily for 7 to 14 days and after the administration of an equivalent amount of $\mathrm{NaHCO}_{3}$ for a similar period of time. At the end of each experimental period studies were performed in which the urine was acutely acidified by the infusion of $200 \mu \mathrm{M}$ per minute of $\mathrm{Na}_{2} \mathrm{SO}_{4}$, then alkalinized by the infusion of $600 \mu \mathrm{M}$ per minute of $\mathrm{NaHCO}_{3}$, using a Bowman constant infusion pump. Urine was collected anaerobically in oiled syringes for $\mathrm{pH}$ and ammonia measurements.

To study the effect of $\mathrm{NH}_{4} \mathrm{Cl}$ and $\mathrm{NaHCO}_{3}$ on the activities of the renal enzymes involved in the production of ammonia, biopsies of kidney cortex were obtained surgically from 12 dogs and the activities of the enzymes compared after the administration of $\mathrm{NH}_{4} \mathrm{Cl}$ and after the administration of $\mathrm{NaHCO}_{3}$. Thus each dog served as its own control. Enzymatic activity was also determined in homogenates of kidneys from both acidotic and normal rats. Six of the 12 dogs were given $8 \mathrm{Gm}$. of $\mathrm{NaHCO}_{3}$ daily for 5 to 21 days, after which time the kidney biopsies and enzyme analyses were performed. The dogs were then given $8 \mathrm{Gm}$. $\mathrm{NH}_{4} \mathrm{Cl}$ daily for 5 to 21 days and the kidney enzyme determinations repeated. In the remaining 6 dogs the procedure was reversed so that $\mathrm{NH}_{4} \mathrm{Cl}$ was given first and $\mathrm{NaHCO}_{3}$ last. Four of the dogs received $100 \mathrm{mEq}$. of $\mathrm{HCl}$ intravenously daily instead of the oral $\mathrm{NH}_{4} \mathrm{Cl}$. This was done in order to circumvent any possible difficulties due to inadequate absorption. At the time of biopsies blood samples were drawn for plasma bicarbonate measurements. Immediately upon removal, the samples of kidney cortex were either weighed and homogenized in 19 volumes of ice cold distilled water to give 5 per cent homogenates, or sliced in the cold with a Stadie-Riggs slicer. The homogenates were assayed for phosphate-activated glutaminase I, pyruvate-activated glutaminase II, glutamic dehydrogenase and glutamic-oxaloacetic transaminase.

\section{METHODS}

The $\mathrm{pH}$ of the urine was measured in an internal glass electrode at $37^{\circ} \mathrm{C}$. using a Cambridge research model $\mathrm{pH}$ meter. The concentration of ammonia in the urine was measured by the method of Conway (18). The total $\mathrm{CO}_{2}$ content of plasma was determined by the method of Van Slyke and Neill (19). Dry weights of the kidney homogenates were determined by drying $5 \mathrm{ml}$. aliquots of the homogenates overnight at $90^{\circ} \mathrm{C}$.

The activity of phosphate-activated glutaminase I was assayed using the method previously described (14). The $\mathrm{pH}$ optimum (8.0) of glutaminase I was the same in the kidneys of rats and dogs, and the rate of ammonia formation was linear over the same range of tissue concentrations ( 5 to $20 \mathrm{mg}$. wet kidney) for both dog and rat kidneys.

The activity of pyruvate-activated glutaminase II was measured by a modification of the method described by Goldstein, Richterich-van Baerle and Dearborn (20). Maximal activity for dog and rat kidney glutaminase II was observed at $\mathrm{pH} 8.8$ to 9.0. The method was modified by substituting $0.5 \mathrm{M}$ Tris buffer $(\mathrm{pH} 9.0)$ for the veronal buffer. At the end of the 30 minute incubation period the reaction was stopped by the addition of $0.2 \mathrm{ml}$. 37.5 per cent $\mathrm{HClO}_{4}$. The samples were centrifuged and ammonia measured on $0.2 \mathrm{ml}$. aliquots of the supernatant by a modification of the microdiffusion method of Seligson and Seligson (21). Rather than using the Nesslers reagent as described by Seligson the ammonia was determined colorimetrically using hypo-chlorous acid and sodium phenate (22).

Glutamine synthetase activity was measured in several different ways: the uptake of ammonia by kidney homogenate in the presence of glutamate and ATP as described by Richterich-van Baerle and associates (23), the formation of $\gamma$-glutamyl hydroxamate as described by Levintow, Meister, Hogeboom and Kuff (24), and the method of Reiner and Hudson (25). Potent activity was demonstrable in rat kidney using all three methods, but no measurable activity was found in dog kidney with any of the methods. Since Levintow and co-workers (24) have adduced evidence that the same enzyme catalyzes both the synthesis of glutamine and the transfer exchange of the $\gamma$-glutamyl amide group, the formation of $\gamma$-glutamyl hydroxamate from glutamine, ADP, and hydroxylamine as described by Levintow and associates (24) was the method finally adopted for the assay of glutamine synthetase activity in rat kidney homogenates. Five-tenths $\mathrm{ml}$. of a 1 per cent homogenate was used in each assay. $\gamma$-Glutamyl hydroxamate was measured by the method of Lipmann and Tuttle (26).

Glutamic dehydrogenase activity was assayed in $0.2 \mathrm{ml}$. of a 1:6 dilution of the 5 per cent homogenate using the method of Olson and Anfinsen (27). Glutamic-oxaloacetic transaminase was assayed in $0.2 \mathrm{ml}$. of a $1: 25$ dilution of the 5 per cent kidney homogenate according to the method of Steinberg and Ostrow (28).

The hydrolysis of glutamine by intact kidney slices was determined by incubating slices of kidney cortex, weighing 50 to $100 \mathrm{mg}$., in $3 \mathrm{ml}$. of oxygenated Ringer's phosphate solution ( $\mathrm{pH} 7.4$ ), containing $49 \mu \mathrm{M}$ glutamine per $\mathrm{ml}$. The reaction was stopped at the end of $30 \mathrm{~min}$ utes by the addition of $0.2 \mathrm{ml}$. 37.5 per cent $\mathrm{HClO}_{4}$. The medium was centrifuged and ammonia was measured in $0.5 \mathrm{ml}$. aliquots of the supernatant.

\section{RESULTS}

The effect of the chronic administration of $\mathrm{NH}_{4} \mathrm{CI}$ and $\mathrm{NaHCO}_{3}$ on the relationship between 


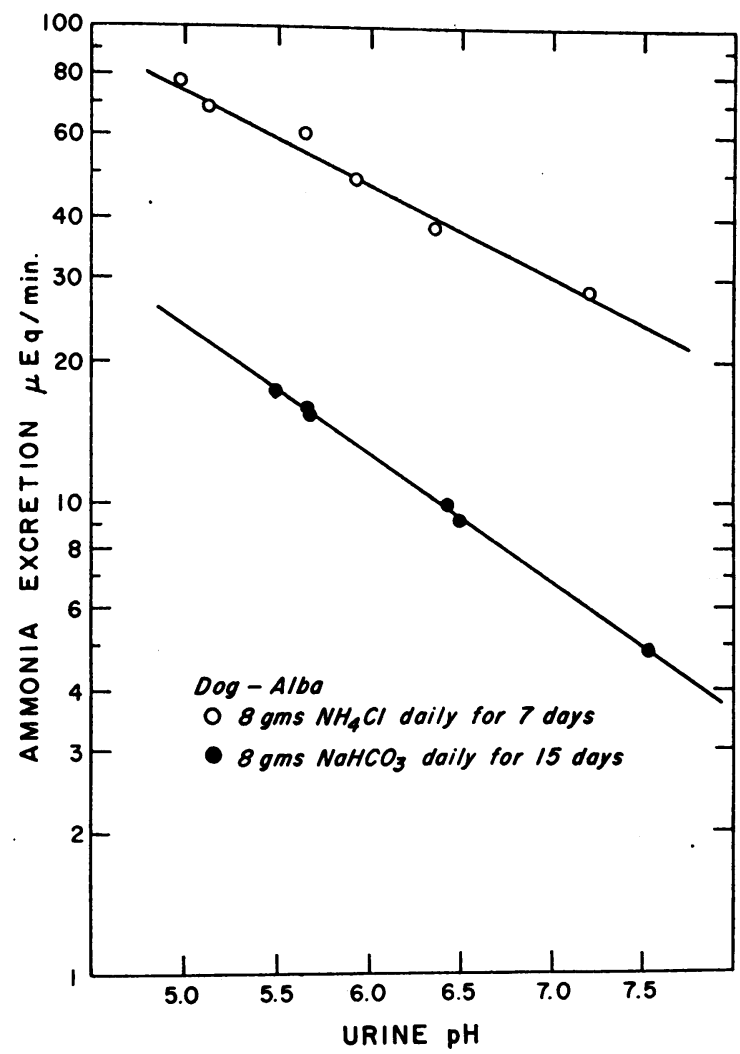

Fig. 1. The Effect of Chronic $\mathrm{NH}_{4} \mathrm{Cl}_{2}$ and $\mathrm{NaHCO}_{3}$ Loads on the Relation Between Ammonia Excretion and URINe PH IN Dogs

ammonia excretion and urine $\mathrm{pH}$ is shown in Figure 1. In both studies a linear relationship between the logarithm of ammonia excretion and urine $\mathrm{pH}$ was observed. Although the slopes of the two lines are approximately the same, the rate of ammonia excretion is three to four times greater at any given urine $\mathrm{pH}$ after $\mathrm{NH}_{4} \mathrm{Cl}$ than after $\mathrm{NaHCO}_{3}$. The results from three other dogs were similar. Adaptive changes in ammonia excretion have also been reported in rats (7) and guinea pigs (29). The results of these studies confirm the observations of Pitts (4) that increased excretion of ammonia after the chronic administration of $\mathrm{NH}_{4} \mathrm{Cl}$ cannot be accounted for on the basis of increased acidity of the urine, but must in some way reflect accelerated production of ammonia by renal tubule cells.

As noted earlier, the studies of Van Slyke and associates (9) indicate that the increased production of ammonia during $\mathrm{NH}_{4} \mathrm{Cl}$ acidosis is a consequence of enhanced hydrolysis of glutamine.
In rats $(7,11,12)$ and guinea pigs (13) this accelerated conversion of glutamine to ammonia is apparently accomplished by an adaptive increase in the activity of renal glutaminase. The results of the present studies, however, indicate that such a mechanism does not account for the increased ammonia excretion in acidotic dogs.

The effect of the chronic administration of $\mathrm{NH}_{4} \mathrm{Cl}$ and $\mathrm{NaHCO}_{3}$ on the renal glutaminases is shown in Table $\mathrm{I}$. In rats $\mathrm{NH}_{4} \mathrm{Cl}$ increased the activity of phosphate-activated glutaminase I approximately fourfold, whereas in dogs $\mathrm{NH}_{4} \mathrm{Cl}$ resulted in a 10 per cent decrease in activity. A similar decrease was noted in four dogs given $\mathrm{HCl}$ intravenously rather than $\mathrm{NH}_{4} \mathrm{Cl}$ orally. Although this decrease in the activity of dog kidney glutaminase I was statistically significant, its physiological significance is obscure. Pyruvate-activated glutaminase II was also increased approximately fourfold in rats given $\mathrm{NH}_{4} \mathrm{Cl}$, but was unchanged in dogs. Glutamine synthetase activity, estimated indirectly from $\gamma$-glutamyl transferase activity, was decreased in rats receiving $\mathrm{NH}_{4} \mathrm{Cl}$, while no activity was measurable in dog kidneys. The depression of glutamine synthetase activity in rat kidneys is in contrast to the results of Richterich-van Baerle and coworkers in which glutamine synthetase activity was increased in guinea pig kidneys by the administration of $\mathrm{NH}_{4} \mathrm{Cl}$. It is unlikely that the failure of glutaminase I and II to increase in dogs during the administration of $\mathrm{NH}_{4} \mathrm{Cl}$ was due to inadequate stimulation, since at the time of biopsy the plasma $\mathrm{HCO}_{3}^{-}$concentrations were $26 \pm 2$ mEq. per L. after $\mathrm{NaHCO}_{3}$ and $21 \pm 2 \mathrm{mEq}$. per L. after $\mathrm{NH}_{4} \mathrm{Cl}$, and the ammonia excretions were $8 \mathrm{mEq}$. per 24 hours after $\mathrm{NaHCO}_{3}$ and $45 \mathrm{mEq}$. per 24 hours after $\mathrm{NH}_{4} \mathrm{Cl}$. Thus it is seen that the dogs were in fact slightly acidotic and were excreting increased amounts of ammonia after the administration of $\mathrm{NH}_{4} \mathrm{Cl}$.

Since the administration of $\mathrm{NH}_{4} \mathrm{Cl}$ did not increase the activity of glutaminase I and II in the cortex of dog kidneys, the possibility of isolated changes occurring in other sections of the kidney was investigated. The activity of glutaminase I was measured in the cortex, medulla and papilla of kidney from dogs given either $\mathrm{NH}_{4} \mathrm{Cl}$ or $\mathrm{NaHCO}_{3}$ and in rats given either $\mathrm{H}_{2} \mathrm{O}$ or 1.5 per cent $\mathrm{NH}_{4} \mathrm{Cl}$ solution ad lib. In both dogs and 
TABLE I

The effect of $\mathrm{NH}_{4} \mathrm{Cl}$ and $\mathrm{NaHCO}_{3}$ on the activity of glutaminase $\mathrm{I}$, glutaminase II and glutamine synthetase in kidney cortex of dogs and rats

\begin{tabular}{|c|c|c|c|c|c|c|c|}
\hline & \multirow[t]{2}{*}{ Group } & \multicolumn{2}{|c|}{ 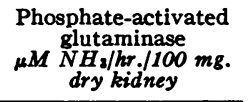 } & \multicolumn{2}{|c|}{$\begin{array}{c}\text { Pyruvate-activated } \\
\text { glutaminase } \\
\text { MM } \begin{array}{c}N H_{z} / / h r / 100 \\
\text { dry kidney }\end{array}\end{array}$} & \multicolumn{2}{|c|}{$\begin{array}{c}\text { Glutamine synthetase } \\
\text { units/hr./100 mg. } \\
\text { wet kidney }\end{array}$} \\
\hline & & Dogs & Rats & Dogs & Rats & Dogs & Rats \\
\hline \multicolumn{2}{|c|}{ No. of animals......... } & 12 & 8 & 4 & 4 & 4 & 4 \\
\hline Controls & $\begin{array}{r}\text { Mean activity } \\
\text { S. D. }\end{array}$ & & $\begin{array}{r}545 \\
\pm 77\end{array}$ & & $\begin{array}{l}101 \\
\pm 31\end{array}$ & & $\begin{array}{r}45.1 \\
\pm 3.9\end{array}$ \\
\hline $\mathrm{NaHCO}_{3}{ }^{*}$ & $\begin{array}{r}\text { Mean activity } \\
\text { S. D. }\end{array}$ & $\begin{array}{r}735 \\
\pm 151\end{array}$ & & $\begin{array}{r}105 \\
\pm 15\end{array}$ & & & \\
\hline \multirow[t]{2}{*}{$\mathrm{NH}_{4} \mathrm{Cl} \dagger$} & $\begin{array}{r}\text { Mean activity } \\
\text { S. D. }\end{array}$ & $\begin{array}{r}665 \\
\pm 175\end{array}$ & $\begin{array}{l}2,120 \\
\pm 412\end{array}$ & $\begin{array}{r}108 \\
\pm 53\end{array}$ & $\begin{array}{r}471 \\
\pm 146\end{array}$ & 0 & $\begin{array}{r}38.0 \\
\pm 2.9\end{array}$ \\
\hline & $\begin{array}{r}\text { Mean difference } \\
\text { S. E. } \\
\text { p }\end{array}$ & $\begin{array}{r}-70 \\
\pm 30 \\
<0.05\end{array}$ & $\begin{array}{r}+1,595 \\
\pm 148 \\
<0.01\end{array}$ & $\begin{array}{l}+3 \\
\pm 22 \\
>0.5\end{array}$ & $\begin{array}{l}+370 \\
\pm 57 \\
<0.01\end{array}$ & & $\begin{array}{r}-7.1 \\
\pm 2.5 \\
<0.05\end{array}$ \\
\hline
\end{tabular}

* The dogs received $8 \mathrm{Gm} . \mathrm{NaHCO}_{3}$ daily for 5 to 21 days.

† The dogs received $8 \mathrm{Gm}$. $\mathrm{NH}_{4} \mathrm{Cl}$ daily for 5 to 21 days; the rats received 1.5 per cent $\mathrm{NH}_{4} \mathrm{Cl}$ in tap water ad lib. for 14 to 21 days.

rats the activity of glutaminase $I$ in the papilla was approximately one-tenth the activity in the cortex. In rats the administration of $\mathrm{NH}_{4} \mathrm{Cl}$ had no effect on the activity of glutaminase $I$ in the papilla, while the activity increased approximately fourfold in the cortex. In dogs the administration of $\mathrm{NH}_{4} \mathrm{Cl}$ did not increase the activity of glutaminase I in either cortex or medulla. A slight increase in activity was observed in the papilla of dogs. However the enzyme and tissue blank constituted such a large fraction of the total ammonia produced that the results were not interpretable. Furthermore the absolute amounts of ammonia produced were so small as to be physiologically insignificant.

Although the activity of the renal glutaminases, as assayed in homogenates, did not increase in dogs given $\mathrm{NH}_{4} \mathrm{Cl}$, the alternative possibility that chronic $\mathrm{NH}_{4} \mathrm{Cl}$ acidosis induces changes in the intracellular environment which increases the effective activity of the enzyme resident in the cell, without changing its actual concentration, was considered. Changes of such a nature would not be detected by assays of tissue homogenates, but might be with intact kidney slices. To investigate this point the rate of glutamine hydrolysis by intact kidney slices was measured. The effect of $\mathrm{NH}_{4} \mathrm{Cl}$ administration is shown in Table II. $\mathrm{NH}_{4} \mathrm{Cl}$ increased the rate of hydrolysis in rats, but decreased the rate by approximately 10 per cent in dogs. Although no evidence for an increase in the effective intracellular activity of dog kidney glutaminase was obtained, the true in vivo activity may not be reflected by the in vitro hydrolysis of glutamine by kidney slices.

Another process whereby the conversion of glutamine to ammonia could be accelerated involves the action of glutamic dehydrogenase. Glutamic

TABLE II

The effect of $\mathrm{NH}_{4} \mathrm{Cl}$ and $\mathrm{NaHCO}_{3}$ on the hydrolysis of glutamine by intact kidney slices

\begin{tabular}{|c|c|c|c|}
\hline & \multirow[t]{2}{*}{ Group } & \multicolumn{2}{|c|}{$\begin{array}{c}\text { Glutamine hydrolysis } \\
\mu M N N_{k i d n e y / h r}\end{array}$} \\
\hline & & Dogs & Rats* \\
\hline \multicolumn{2}{|c|}{ No. of animals. } & 4 & 12 \\
\hline $\mathrm{NaHCO}_{3} \dagger$ & $\begin{array}{r}\text { Mean activity } \\
\text { S. D. }\end{array}$ & $\begin{array}{r}7.7 \\
\pm 0.7\end{array}$ & $\begin{array}{r}5.5 \\
\pm 0.8\end{array}$ \\
\hline \multirow[t]{2}{*}{$\mathrm{NH}_{4} \mathrm{Cl} \ddagger$} & $\begin{array}{r}\text { Mean activity } \\
\text { S. D. }\end{array}$ & $\begin{array}{r}7.2 \\
\pm 1.0\end{array}$ & $\begin{array}{r}14.0 \\
\pm 2.3\end{array}$ \\
\hline & $\begin{array}{r}\text { Mean difference } \\
\text { S. E. } \\
\text { p }\end{array}$ & $\begin{array}{l}-0.45 \\
\pm 0.36 \\
>0.30\end{array}$ & $\begin{array}{l}+8.4 \\
\pm 0.7 \\
<0.01\end{array}$ \\
\hline
\end{tabular}

* Unpublished data of J. Orloff.

† The dogs received $8 \mathrm{Gm}$. $\mathrm{NaHCO}_{3}$ daily for 10 to 14 days; the rats received 1.5 per cent $\mathrm{NaHCO}_{3}$ solution ad lib. for 14 days.

$\ddagger$ The dogs received $8 \mathrm{Gm}$. $\mathrm{NH}_{4} \mathrm{Cl}$ daily for 10 to 14 days; the rats received 1.5 per cent $\mathrm{NH}_{4} \mathrm{Cl}$ solution ad lib. for 14 days. 
TABLE III

The effect of $\mathrm{NH}_{4} \mathrm{Cl}$ and $\mathrm{NaHCO}_{3}$ on glutamic dehydrogenase and glutamic-oxaloacetic transaminase in kidney cortex of dogs and rats

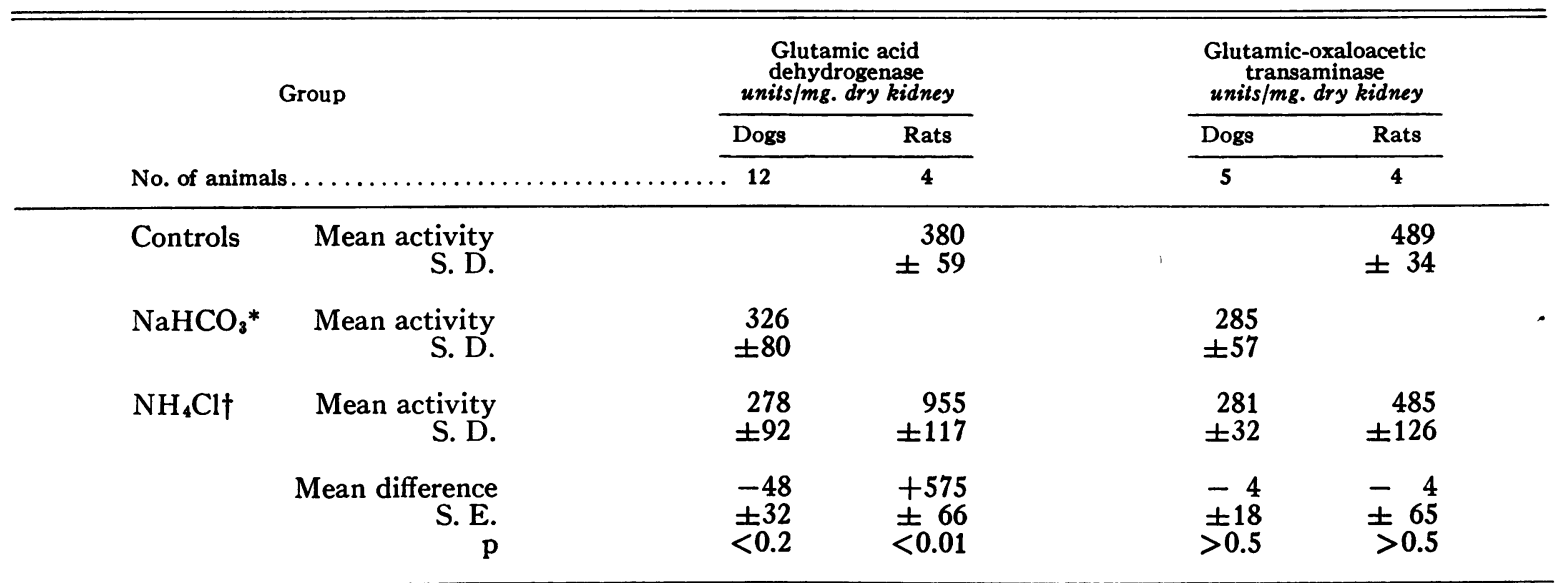

* Dogs received $8 \mathrm{Gm} . \mathrm{NaHCO}_{3}$ daily for 5 to 21 days.

† Dogs received $8 \mathrm{Gm}$. $\mathrm{NH}_{4} \mathrm{Cl}$ daily for 5 to 21 days; rats received 1.5 per cent $\mathrm{NH}_{4} \mathrm{Cl}$ ad lib. for 14 to 21 days.

acid, an end product of glutamine hydrolysis, is known to inhibit glutaminase I (30). An increase in the activity of glutamic dehydrogenase, by increasing the rate of glutamic acid removal, would increase the effective activity of glutaminase I. Also the action of glutamic dehydrogenase would permit glutamine to contribute its amino- $\mathrm{N}$ as well as its amide- $\mathrm{N}$ to urinary ammonia. As seen in Table II the administration of $\mathrm{NH}_{4} \mathrm{Cl}$ increased the activity of glutamic dehydrogenase by approximately threefold in rats, but decreased the activity slightly in dogs.

The participation of ammonia precursors other than glutamine in the increased formation of ammonia during $\mathrm{NH}_{4} \mathrm{Cl}$ acidosis was also investigated. Davies and Yudkin (11) found that in addition to renal glutaminase, L-amino acid oxidase and glycine oxidase were increased in the kidneys of rats given $\mathrm{HCl}$. Although, no L-amino acid oxidase has been found in dog kidney (31), infusions of amino acids are known to stimulate ammonia excretion in dogs $(6,10,32)$. The probable pathway involved is transamination of the amino acid with $\gamma$-keto glutarate to form glutamate, which is then deaminated. The possibility that this pathway was responsible for the increased production of ammonia in acidotic dogs was studied. However, the administration of $\mathrm{NH}_{4} \mathrm{Cl}$ produced no changes in the activity of glutamic-oxaloacetic transaminase in either dogs or rats (Table III).
DISCUSSION

Recent investigations of the physicochemical factors influencing ammonia excretion $(6,8,33)$ support the hypothesis that ammonia transverses the tubule cell membrane as the unionized lipoid soluble $\mathrm{NH}_{3}$, and that, except for very acid urines, equilibrium between cell and luminal $\mathrm{NH}_{3}$ is attained. Since the $\mathrm{NH}_{4}{ }^{+}$ion appears to be relatively nondiffusible across the cell membrane and is in rapid equilibrium with $\mathrm{NH}_{8}$, the accumulation of $\mathrm{NH}_{4}{ }^{+}$in the urine is dependent on urine $\mathrm{pH}$, more accumulating in acid than in alkaline urines. In addition, any factor which changes the concentration of ammonia within the cell alters ammonia excretion more or less independently of urine $\mathrm{pH}$. Thus, infusions of glutamine and other amino acids elevate ammonia excretion despite alkalinization of the urine $(6,32)$.

During the chronic administration of $\mathrm{NH}_{4} \mathrm{Cl}$ cellular factors appear to be more important in regulating ammonia excretion than is urine $\mathrm{pH}$. Animals receiving $\mathrm{NH}_{4} \mathrm{Cl}$ excrete more ammonia at any given urine $\mathrm{pH}$ than do control animals, indicating that the concentration of ammonia in the tubule cell has risen, presumably due to increased production of ammonia.

The increased production of ammonia during $\mathrm{NH}_{4} \mathrm{Cl}$ acidosis appears to be related primarily to the hydrolysis of glutamine (9), and to a lesser extent to the deamination of other amino acids 
(9). In rats elevation of the activity of the renal ammonia-producing enzymes appears to be responsible for the accelerated production of ammonia $(7,11,12)$. The administration of $\mathrm{NH}_{4} \mathrm{Cl}$ produces striking increases in the activity of glutaminase I, glutaminase II, glutamic dehydrogenase, L-amino acid oxidase and glycine oxidase. In dogs, however, adaptation of the renal ammonia-producing enzymes does not participate in the regulation of ammonia excretion. In the present experiments, the administration of $\mathrm{NH}_{4} \mathrm{Cl}$ failed to increase the activity of glutaminases I and II, glutamic dehydrogenase and glutamic oxaloacetic transaminase in dog kidney homogenates. Also the rate of glutamine hydrolysis by intact kidney slices was unchanged by the administration of $\mathrm{NH}_{4} \mathrm{Cl}$. These findings leave unexplained the mechanism for both the increased production of ammonia during acidosis and the increased extraction of glutamine from the renal arterial blood of acidotic dogs as reported by Van Slyke and associates (9).

Although the present studies would indicate that renal glutaminase is not an adaptive-type enzyme system in dogs, Iacobellis, Muntwyler and Griffin (34) have reported that glutaminase activity was increased in the kidneys of two potassium deficient dogs. This is similar to the adaptive increase in enzyme activity noted in hypokalemic rats by Seldin, Rector, Carter and Copenhaver (35) and Iacobellis and co-workers (36). However, the finding of elevated glutaminase activity in potassium deficient dogs could not be confirmed when the activity of glutaminase $I$ in kidney biopsy samples from four hypokalemic dogs was compared with activity in the kidney biopsies from the same dogs during control periods (37).

In summary, the present studies reveal that the adaptation of renal enzymes, which constitutes an important regulatory mechanism of ammonia in rats and guinea pigs, is not a process common to all species. This finding may be of considerable significance with respect to the regulation of ammonia excretion in man. Ammonia excretion in man more closely resembles that of the $d o g$ in that the logarithm of ammonia excretion is linearly related to urine $\mathrm{pH}(8)$, and urinary ammonia is persistently reduced during chronic carbonic anhydrase inhibition (16). However, more direct studies are needed to clarify the role of the ammonia-producing enzymes in the regulation of ammonia excretion in man.

\section{SUMMARY}

An adaptive increase in ammonia excretion following the chronic administration of $\mathrm{NH}_{4} \mathrm{Cl}$ is known to occur in the dog. This, as well as the decrease in ammonia excretion following chronic bicarbonate administration, has been confirmed.

The adaptive changes in ammonia excretion are not accompanied by alterations in the activities of any of the renal enzymes known to be involved directly or indirectly in the conversion of glutamine to ammonia. In contrast to findings in the rat, $\mathrm{NH}_{4} \mathrm{Cl}$ did not increase the activity of glutaminase I, glutaminase II, glutamic dehydrogenase and glutamic oxaloacetic transaminase in kidney homogenates. Furthermore enzymatic hydrolysis of glutamine by intact kidney slices was unaltered.

\section{REFERENCES}

1. Briggs, A. P. The significance of the urinary ammonia. J. Lab. clin. Med. 1942, 28, 174.

2. Wolf, A. V. Renal regulation of water and some electrolytes in man, with special reference to their relative retention and excretion. Amer. J. Physiol. 1947, 148, 54.

3. Sartorious, O. W., Roemmelt, J. C., and Pitts, R. F. The renal regulation of acid-base balance in man. IV. The nature of the renal compensations in ammonium chloride acidosis. J..clin. Invest. 1949, 28, 423.

4. Pitts, R. F. Renal excretion of acid. Fed. Proc. 1948, 7, 418.

5. Ferguson, E. B., Jr. A study of the regulation of the rate of urinary ammonia excretion in the rat. $\mathrm{J}$. Physiol. 1951, 112, 420.

6. Orloff, J., and Berliner, R. W. The mechanism of the excretion of ammonia in the dog. J. clin. Invest. 1956, 35, 223.

7. Leonard, E., and Orloff, J. Regulation of ammonia excretion in the rat. Amer. J. Physiol. 1955, 182, 131.

8. Clarke, E., Evans, B. M., MacIntyre, I., and Milne, M. D. Acidosis in experimental electrolyte depletion. Clin. Sci. 1955, 14, 421.

9. Van Slyke, D. D., Phillips, R. A., Hamilton, P. B., Archibald, R. M., Futcher, P. H., and Hiller, A. Glutamine as source material of urinary ammonia. J. biol. Chem. 1943, 150, 481.

10. Lotspeich, W. D., and Pitts, R. F. The role of amino acids in the renal tubular secretion of ammonia. J. biol. Chem. 1947, 168, 611. 
11. Davies, B. M. A., and Yudkin, J. Studies in biochemical adaption. The origin of urinary ammonia as indicated by the effect of chronic acidosis and alkalosis on some renal enzymes in the rat. Biochem. J. 1952, 52, 407.

12. Rector, F. C., Jr., Seldin, D. W., and Copenhaver, J. $H$. The mechanism of ammonia excretion during ammonium chloride acidosis. $\mathrm{J}$. clin. Invest. 1955, 34, 20.

13. Goldstein, L., Richterich-van Baerle, R., and Dearborn, E. H. Increased activity of renal glutaminases in guinea pig following prolonged administration of acid or alkali. Proc. Soc. exp. Biol. (N. Y.) 1956, 93, 284.

14. Rector, F. C., Jr., Seldin, D. W., Roberts, A. D., Jr., and Copenhaver, J. H. The relation of ammonia excretion to urine pH. Amer. J. Physiol. 1954, 179, 353.

15. Maren, T. H., Wadsworth, B. C., Yale, E. K., and Alonso, L. G. Carbonic anhydrase inhibition. III. Effects of diamox on electrolyte metabolism. Bull. Johns Hopk. Hosp. 1954, 95, 277.

16. Counihan, T. B., Evans, B. M., and Milne, M. D. Observations on the pharmacology of the carbonic anhydrase inhibitor "diamox." Clin. Sci. 1954, 13, 583.

17. Orloff, $J$. The role of the kidney in the regulation of acid-base balance. Yale J. Biol. Med. 1956, 29, 211.

18. Conway, E. J. Microdiffusion Analysis and Volumetric Error, 3d ed. London, C. Lockwood, 1950.

19. Van Slyke, D. D., and Neill, J. M. The determination of gases in blood and other solutions by vacuum extraction and manometric measurement. I. J. biol. Chem. 1924, 61, 523.

20. Goldstein, L., Richterich-van Baerle, R., and Dearborn, E. H. Kidney glutaminases. II: The glutamine- $\alpha$-keto acid transamination-deamidation system of the guinea pig. Enzymologia 1957, 18, 261.

21. Seligson, D., and Seligson, H. A microdiffusion method for the determination of nitrogen liberated as ammonia. J. Lab. clin. Med. 1951, 38, 324.

22. Scheurer, P. G., and Smith, F. Colorimetric submicromethod for determination of ammonia. Analyt. Chem. 1955, 27, 1616.

23. Richterich-van Baerle, R., Goldstein, L., and Dearborn, E. H. Kidney glutaminases. III : Glutamine synthesis in the guinea pig kidney. Enzymologia $1957,18,327$.

24. Levintow, L., Meister, A., Hogeboom, G. H., and Kuff, E. L. Studies on the relationship between the enzymatic synthesis of glutamine and the glutamyl transfer reaction. J. Amer. chem. Soc. 1955, 77, 5304.

25. Reiner, J. M., and Hudson, P. B. Effect of age upon glutamine synthesis and glutamine amide exchange of rat liver, kidney and testis. J. Urol. 1953, 70, 627.

26. Lipmann, F., and Tuttle, L. C. A specific micromethod for the determination of acyl phosphates. J. biol. Chem. 1945, 159, 21.

27. Olson, J. A., and Anfinsen, C. B. The crystallization and characterization of $\mathrm{L}$-glutamic acid dehydrogenase. J. biol. Chem. 1952, 197, 67.

28. Steinberg, D., and Ostrow, B. H. Serum transaminase as a measure of myocardial necrosis. Proc. Soc. exp. Biol. (N. Y.) 1955, 89, 31.

29. Richterich-van Baerle, R., and Goldstein, L. Renal ammonia production as a model for the study of enzyme adaptation in mammals. Experientia (Basel) 1957, 13, 30.

30. Krebs, H. A. Metabolism of amino acids. IV. The synthesis of glutamine from glutamic acid and ammonia, and the enzymatic hydrolysis of glutamine in animal tissues. Biochem. J. 1935, 29, 1951.

31. Blanchard, M., Green, D. E., Nocito, V., and Ratner, S. l-Amino acid oxidase of animal tissue. J. biol. Chem. 1944, 155, 421.

32. Kamin, H., and Handler, P. The metabolism of parenterally administered amino acids. III. Ammonia formation. J. biol. Chem. 1951, 193, 873.

33. Milne, M. D., Scribner, B. H., and Crawford, M. A. Non-ionic diffusion and the excretion of weak acids and bases. Amer. J. Med. 1958, 24, 709.

34. Iacobellis, M., Muntwyler, E., and Griffin, G. E. Kidney glutaminase and carbonic anhydrase activity and tissue electrolyte composition in potassium-deficient dogs. Amer. J. Physiol. 1955, 183, 395.

35. Seldin, D. W., Rector, F. C., Jr., Carter, N., and Copenhaver, J. The relation of hypokalemic alkalosis induced by adrenal steroids to renal acid secretion (abstract). J. clin. Invest. 1954, 33, 965.

36. Iacobellis, M., Muntwyler, E., and Griffin, G. E. Enzyme concentration changes in the kidneys of protein and/or potassium-deficient rats. Amer. J. Physiol. 1954, 178, 477.

37. Rector, F. C., Jr., and Orloff, J. Unpublished observations. 